\title{
Interaction of Biochar Amendment and Nitrogen Deposition on Soil Microbial Biomass Carbon and Enzyme Activity in a Torreya grandis Orchard
}

\author{
Bingwen Chai, Jianhua Lv, Quan Li, Jiasheng Wu*, Xinzhang Song** \\ State Key Laboratory of Subtropical Silviculture, Zhejiang A\&F University, Hangzhou, China
}

Received: 16 April 2018

Accepted: 10 September 2018

\begin{abstract}
The objective of this study was to test whether biochar amendment could offset the effects of nitrogen $(\mathrm{N})$ deposition on soil microbial biomass carbon (MBC) and enzyme activity. We applied $\mathrm{N}$ (low and high rates) and biochar (low and high rates) individually, and in combination (all permutations) to the soil of a Torreya grandis cv. "Merrillii" orchard as a 13-month field experiment during 20152016 in Zhejiang Province, China. MBC significantly increased in the low N treatment but decreased in the high $\mathrm{N}$ treatment $(P<0.05)$. MBC significantly decreased in both biochar-only treatments, and this effect became stronger as biochar amendment rates increased. Biochar amendment amplified the positive effects of low $\mathrm{N}$ treatment on $\mathrm{MBC}$ and mitigated the negative effects of high $\mathrm{N}$ treatment. Catalase, cellulase, and urease activities significantly increased with $\mathrm{N}$ addition. Cellulase, nitrite reductase, and urease activities significantly increased in the biochar treatments. The positive effects of low $\mathrm{N}$ addition on catalase were amplified in the low biochar amendment treatment, but the positive effects on cellulase decreased significantly. The effects of biochar amendment on MBC and enzyme activities of soil that receives atmospheric $\mathrm{N}$ deposition were regulated by the rates of both biochar amendment and $\mathrm{N}$ deposition, and varied with enzyme type.
\end{abstract}

Keywords: biochar, microorganism, nitrogen addition, orchard, Torreya grandis cv. "Merrillii“"

\section{Introduction}

In recent decades, nitrogen $(\mathrm{N})$ deposition has rapidly increased owing to increases in the burning of fossil fuel and the utilization of fertilizers in agriculture

*e-mail: wujs@zafu.edu.cn

**e-mail: songxinzhang@gmail.com
[1]. This phenomenon has strongly impacted subtropical China, which has incurred a maximum annual $\mathrm{N}$ deposition rate of $63.53 \mathrm{~kg} \mathrm{~N} \mathrm{ha} \mathrm{kgr}^{-1} \mathrm{yr}^{-1}$ and is predicted to become the region with the highest $\mathrm{N}$ deposition in the world by 2030 [2]. Soil microbial biomass plays a critical role in soil fertility, and microbial biomass carbon (MBC) can be effectively used as an index to evaluate soil quality [3]. Some studies have found that $\mathrm{N}$ input significantly decreases $\mathrm{MBC}$ 
[4-6]. However, Johnson et al. [7] found that long-term $\mathrm{N}$ deposition increased $\mathrm{MBC}$ in heathlands, but decreased it in acid and calcareous grasslands; Boxman et al. [8] observed that $\mathrm{N}$ addition does not affect the biomass of fungi and bacteria. In addition, $\mathrm{N}$ deposition may accelerate soil acidification [9], and have positive or negative effects on soil enzyme activities by altering soil $\mathrm{N}$ availability and plant litter decomposition [10].

Biochar is a byproduct of the thermal combustion (termed pyrolysis) of biomass in the absence of oxygen at relatively low temperatures $\left(300-700^{\circ} \mathrm{C}\right)$ [11]. It is thought to be intrinsically resistant to microbial decomposition owing to its condensed poly-aromatic structures [12]. It is commonly alkaline and is therefore usually applied to neutralize acidic soils and to increase soil $\mathrm{pH}$ [13]. Previous studies have shown that biochar amendment increased soil MBC in the plains of northern China during the maize-growing season [14]; in the hilly red soil region of southern China, which has soils that are generally low in fertility [15], it increased microbial activity in highly weathered soils [16]. However, a meta-analysis of studies on this topic showed that a high rate of biochar amendment has a negative effect on MBC [17]. Feng et al. [18] observed that biochar amendment inhibits soil catalase and neutralizes phosphatase activities in potted wheat. However, it is still unknown whether biochar amendment can neutralize the effects of atmospheric $\mathrm{N}$ deposition on soil biotic properties due to its alkaline character - especially in orchard environments.

Torreya grandis cv. "Merrillii" is a coniferous tree in the Cephalotaxaceae family that yields a rare and unique dried fruit. The fruit is easily digestible, and has many beneficial effects on human health [19]. Due to its high nutritional value, the planting area of T. grandis has been expanded rapidly, and it therefore plays an increasingly important role in improving the income of farmers in subtropical China [19]. However, growers of $T$. grandis are faced with soil acidification throughout its growing range as a result of increased atmospheric $\mathrm{N}$ deposition. It remains unclear whether a biochar amendment can alleviate the acidifying effect of $\mathrm{N}$ deposition. Therefore, for this study, a 13-month field experiment was undertaken to test the following hypotheses: (1) $\mathrm{N}$ deposition increases soil $\mathrm{MBC}$ and enzyme activities; (2) biochar amendment decreases soil MBC and enzyme activities; and (3) biochar amendment offsets the effects of $\mathrm{N}$ deposition.

\section{Material and Methods}

\section{Study Site}

The study site was located in the town of Yuqian within Lin'an City, Zhejiang Province, China (30 $14^{\prime} \mathrm{N}$, $\left.119^{\circ} 42^{\prime} \mathrm{E}\right)$. The climate at the study site is subtropical monsoonal with a mean annual precipitation of $1613.9 \mathrm{~mm}$. The mean annual temperature is $16^{\circ} \mathrm{C}$ with a mean annual low of $4.5^{\circ} \mathrm{C}$ (January) and a mean annual high of $29^{\circ} \mathrm{C}$ (July). The area has 237 frost-free days a year. The soil is categorized as belonging to the yellow-red soil class (Chinese system of soil classification, which is equivalent to the Hapludult soil class in soil taxonomy).

\section{Experimental Design}

The T. grandis orchard was established in 1986. In April 2015, 27 T. grandis trees with similar height, basal diameter, and canopy breadth were selected for use in the study, and a corresponding $4 \times 4 \mathrm{~m}$ plot was established around each sample tree. The initial stand and soil characteristics of the orchard are summarized in Table 1. The experiments were conducted following published methods, with some modifications, for simulating $\mathrm{N}$ deposition [20, 21] and determining local $\mathrm{N}$ deposition rates $\left(30.9 \mathrm{~kg} \mathrm{~N} \mathrm{ha}^{-1} \cdot \mathrm{yr}^{-1}\right)$ [22, 23]; the low-N treatments used $30 \mathrm{~kg} \mathrm{~N} \mathrm{ha}{ }^{-1} \cdot \mathrm{yr}^{-1}$ (N30), and the high $\mathrm{N}$ treatments $60 \mathrm{~kg} \mathrm{~N} \mathrm{ha}{ }^{-1} \mathrm{yr}^{-1}$ (N60). Biochar amendment treatments were 20 tonnes $\mathrm{ha}^{-1}$ (BC20) and 40 tonnes ha $^{-1}$ (BC40) treatments. The four combined treatments consisted of all permutations of the two $\mathrm{N}$ and two biochar treatments $(\mathrm{N} 30+\mathrm{BC} 20$, $\mathrm{N} 30+\mathrm{BC} 40, \mathrm{~N} 60+\mathrm{BC} 20, \mathrm{~N} 60+\mathrm{BC} 40)$, and a control (without $\mathrm{N}$ or biochar addition) was also implemented. There were three replicate plots per treatment.

In May 2015, biochar was added to the soil, and the top $30 \mathrm{~cm}$ was mixed uniformly by manual ploughing [24]. Nitrogen addition also began in May 2015. $\mathrm{NH}_{4}^{+}$ and $\mathrm{NO}_{3}{ }^{-}$were reported to account for $56.1 \%$ and $43.9 \%$, respectively, of local wet nitrogen deposition. $\mathrm{NH}_{4} \mathrm{NO}_{3}$ was used as the $\mathrm{N}$ source to simulate atmospheric $\mathrm{N}$ deposition, as it is considered to be the closest available to the chemistry of atmospheric $\mathrm{N}$ deposition [21]. Quantitative $\mathrm{NH}_{4} \mathrm{NO}_{3}$ was dissolved in water and evenly sprayed from the top of the $T$. grandis canopy using an electric sprayer once per month onto the plots that received the $\mathrm{N}$ treatment. The plots that did not receive $\mathrm{N}$ were sprayed with an equal amount of $\mathrm{N}$-free water.

\section{Biochar Characteristics}

The biochar used in this study was produced by Sanli New Energy Company (Shangqiu, China) from wheat straw at a temperature of about $450^{\circ} \mathrm{C}$ under anoxic conditions. The original biochar mass was ground so that it could pass through a $2 \mathrm{~mm}$ sieve, and then mixed thoroughly to obtain a fine granular consistency. The characteristics of the biochar obtained were as follows: $\mathrm{pH}\left(\mathrm{H}_{2} \mathrm{O}\right)$ : 9.8 , bulk density: $0.5 \mathrm{~g} \cdot \mathrm{cm}^{-3}$, surface area: $9.7 \mathrm{~m}^{2} \cdot \mathrm{g}^{-1}$, cation exchange capacity (CEC): $189.3 \mathrm{c} \cdot \mathrm{mol} \cdot \mathrm{kg}^{-1}$, organic carbon content: $425.3 \mathrm{~g} \cdot \mathrm{kg}^{-1}$, total $\mathrm{N}$ content: $5.2 \mathrm{~g} \cdot \mathrm{kg}^{-1}$, total phosphorus (P) content: $3.4 \mathrm{~g} \cdot \mathrm{kg}^{-1}$, and ash content: $18.6 \%$. 


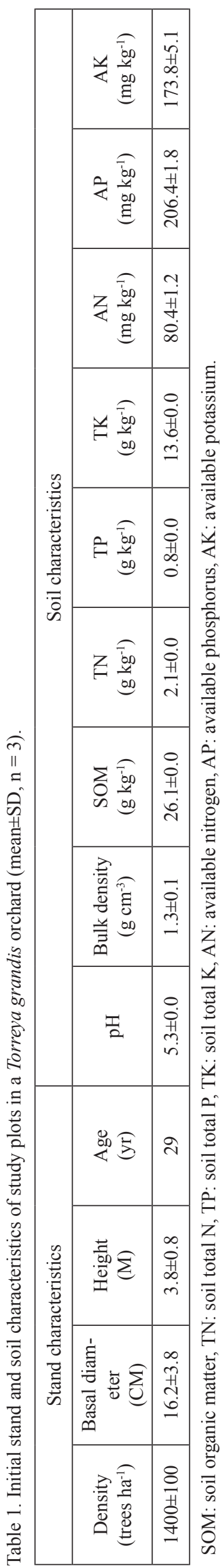

\section{Soil Sampling}

In June 2016, three soil samples were randomly collected as soil cores from each plot. Samples were taken from the top $20 \mathrm{~cm}$ of the soil, $80 \mathrm{~cm}$ away from the tree trunk. The samples were mixed until homogenous, and then transported to the laboratory in an incubator. The samples were sieved through $2 \mathrm{~mm}$ mesh to remove plant residues, stones, and roots. Part of the fresh sample was then used to determine the $\mathrm{MBC}$. The remaining sample was then used to measure enzyme activity and the physicochemical properties of the soil [25].

\section{Analysis of Soil Microbial Biomass and Soil Physiochemical Properties}

MBC was measured using the chloroform fumigation extraction method. Soil organic matter was estimated using dichromate oxidation method. Total nitrogen was determined using an automatic Kjeldahl distillation-titration unit (Foss, Hillerød, Denmark); available nitrogen was determined by titration against a standard $0.01 \mathrm{~mol} \mathrm{~L}^{-1} \mathrm{H}_{2} \mathrm{SO}_{4}$ solution. Total phosphorus and available phosphorus content were measured by the molybdenum blue method, using a spectrophotometer (UV2550, Shimadzu, Kyoto, Japan). Total potassium was determined by $\mathrm{NaOH}$ fusion method. The available potassium was measured using the $2 \mathrm{~mol} \cdot \mathrm{L}^{-1}$ cold $\mathrm{HNO}_{3}$ method. The $\mathrm{pH}$ was determined in a soil-water extract $(1: 2.5 \mathrm{w} / \mathrm{v})$ using a $\mathrm{pH}$ meter (FE20, Mettler Toledo, Switzerland) after shaking for 30 minutes. The activities of soil enzymes were estimated following the methods suggested by Guan [26].

\section{Statistical Analyses}

A one-way analysis of variance (ANOVA) was used to determine whether statistically significant differences existed between MBC or enzyme activities between the treatments. Pairwise comparisons were then conducted to identify which of the treatments were significantly different using a least-significant difference (LSD) test. Two-way ANOVAs were performed to assess the combined effects of $\mathrm{N}$ deposition and biochar amendment on MBC and enzyme activity. Analyses were conducted using SPSS (Statistical Package for the Social Sciences) version 18.0 for Windows (SPSS Inc., Chicago, Illinois, USA).

\section{Results and Discussion}

\section{Data Analysis of Soil Microbial Biomass Carbon and Enzyme Activity}

The soil MBC was $7 \%, 65 \%$, and $33 \%$ lower in the $\mathrm{BC} 20, \mathrm{BC} 40$, and $\mathrm{N} 60$ treatments, respectively, than in the control; however, soil MBC was $31 \%$ 


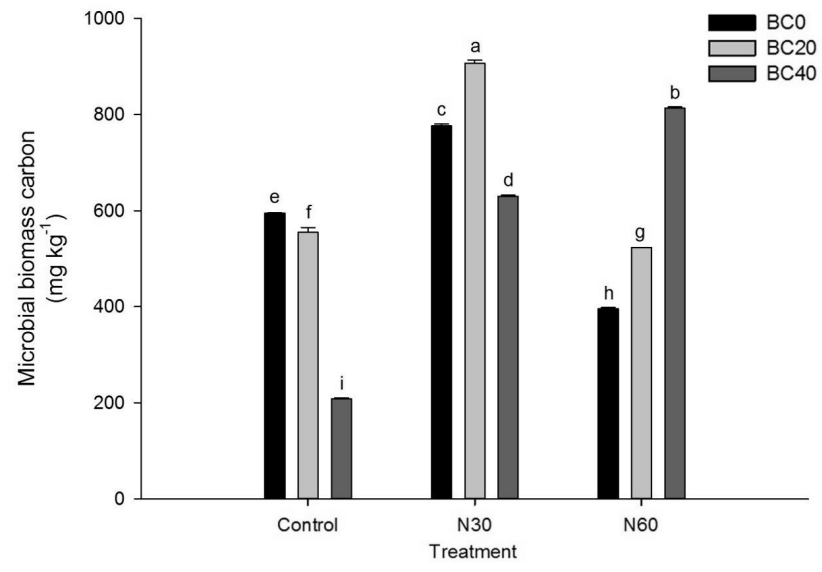

Fig. 1. Soil microbial biomass carbon (MBC) contents under nitrogen and biochar addition treatments in a Torreya grandis orchard. N30: $30 \mathrm{~kg} \mathrm{~N} \mathrm{ha}^{-1} \mathrm{yr}^{-1}$; N60: $60 \mathrm{~kg} \mathrm{~N} \mathrm{ha}^{-1} \cdot \mathrm{yr}^{-1}$. BC20: $20 \mathrm{t}$ biochar ha ${ }^{-1}$; $\mathrm{BC} 40$ : $40 \mathrm{t}$ biochar $\mathrm{ha}^{-1}$. Data are the means of three replicates $( \pm \mathrm{SE})$. Different letters indicate significant differences at $P<0.05$. higher in the N30 treatment than in the control (Fig. 1). Soil MBC significantly increased in the N30+BC20 treatment but significantly decreased in the $\mathrm{N} 30+\mathrm{BC} 40$ treatment, compared with the soil $\mathrm{MBC}$ in the N30 treatment (Fig. 1). The soil $\mathrm{MBC}$ also significantly increased in the $\mathrm{N} 60+\mathrm{BC} 20$ and $\mathrm{N} 60+\mathrm{BC} 40$ treatments compared with the soil $\mathrm{MBC}$ in the N60 treatment (Fig. 1). A two-way ANOVA showed that $\mathrm{N}$ deposition, biochar amendment, and their interaction all significantly affected soil MBC (Table 2).

In general, catalase activity was significantly higher in the $\mathrm{N} 30, \mathrm{~N} 30+\mathrm{BC} 20$, and $\mathrm{N} 60+\mathrm{BC} 20$ treatments than in the control. Catalase activity significantly increased in the N30 plots with BC20 amendment, compared with that of the N30 plots (Fig. 2a). A two-way ANOVA showed that $\mathrm{N}$ and biochar addition individually significantly affected catalase activity, but that their interaction was not significant (Table 2)

Cellulase activity was significantly higher in the BC20, N30, N30+BC20, N60, and N60+BC40 treatments than in the control, but it decreased significantly in the $\mathrm{N} 30+\mathrm{BC} 40$ treatment (Fig. 2b). A two-way ANOVA also showed that the interaction of $\mathrm{N}$ and biochar

Table 2. Results of a two-way ANOVA of the effects of nitrogen deposition and biochar amendment on soil microbial biomass carbon (MBC) and enzyme activities in a Torreya grandis orchard.

\begin{tabular}{|c|c|c|c|c|}
\hline Category & Difference source & SS & $\mathrm{F}$ & $P$-value \\
\hline \multirow{3}{*}{$\mathrm{MBC}$} & Nitrogen deposition & 463742.7 & 10805.32 & $<0.001$ \\
\hline & Biochar amendment & 57324.61 & 1335.678 & $<0.001$ \\
\hline & Interaction & 603974.9 & 7036.385 & $<0.001$ \\
\hline \multirow{3}{*}{ Catalase } & Nitrogen deposition & 0.167537 & 6.904949 & $<0.01$ \\
\hline & Biochar amendment & 0.122005 & 5.028389 & $<0.05$ \\
\hline & Interaction & 0.134052 & 2.762434 & 0.06 \\
\hline \multirow{3}{*}{ Cellulase } & Nitrogen deposition & 4.375425 & 2.374741 & 0.12 \\
\hline & Biochar amendment & 2.769953 & 1.503379 & 0.25 \\
\hline & Interaction & 11.21903 & 3.044537 & $<0.05$ \\
\hline \multirow{3}{*}{ Nitrate reductase } & Nitrogen deposition & 0.009375 & 1.512764 & 0.25 \\
\hline & Biochar amendment & 0.003021 & 0.487522 & 0.62 \\
\hline & Interaction & 0.015398 & 1.242308 & 0.33 \\
\hline \multirow{3}{*}{ Nitrite reductase } & Nitrogen deposition & 428.3918 & 2.398296 & 0.12 \\
\hline & Biochar amendment & 691.7958 & 3.872929 & $<0.05$ \\
\hline & Interaction & 4648.752 & 13.01272 & $<0.001$ \\
\hline \multirow{3}{*}{ Urease } & Nitrogen deposition & 0.982332 & 5.641632 & $<0.05$ \\
\hline & Biochar amendment & 0.698866 & 4.013655 & $<0.05$ \\
\hline & Interaction & 0.661357 & 1.899121 & 0.15 \\
\hline \multirow{3}{*}{$\beta$-fructofuranosidase } & Nitrogen deposition & 10.43604 & 15.21699 & $<0.001$ \\
\hline & Biochar amendment & 8.221304 & 11.98764 & $<0.001$ \\
\hline & Interaction & 7.427232 & 5.414895 & $<0.01$ \\
\hline
\end{tabular}


significantly affected cellulase activity, although $\mathrm{N}$ and biochar addition individually did not (Table 2).

Nitrate reductase activity did not vary significantly under any treatment trialed in this study (Fig. 2c; Table 2). Nitrite reductase activity, however, was significantly higher in the $\mathrm{BC} 20, \mathrm{~N} 30+\mathrm{BC} 20$, and $\mathrm{N} 60+\mathrm{BC} 40$ treatments than in the control. Nitrite reductase activity significantly decreased in the $\mathrm{N} 30+\mathrm{BC} 40$ and N60+BC20 treatments (Fig. 2d). A twoway ANOVA showed that biochar amendment (both by itself and combined with $\mathrm{N}$ addition) significantly affected nitrite reductase activity (Table 2).

Urease activity was significantly higher in the $\mathrm{BC} 40$ and N60 treatments, and their interaction, than in the control (Fig. 2e). In addition, a two-way ANOVA showed that $\mathrm{N}$ and biochar addition significantly affected urease activity individually, but that their interaction was not significant (Table 2).

Finally, the activity of $\beta$-fructofuranosidase was significantly higher in the $\mathrm{N} 60+\mathrm{BC} 20$ and $\mathrm{N} 60+\mathrm{BC} 40$
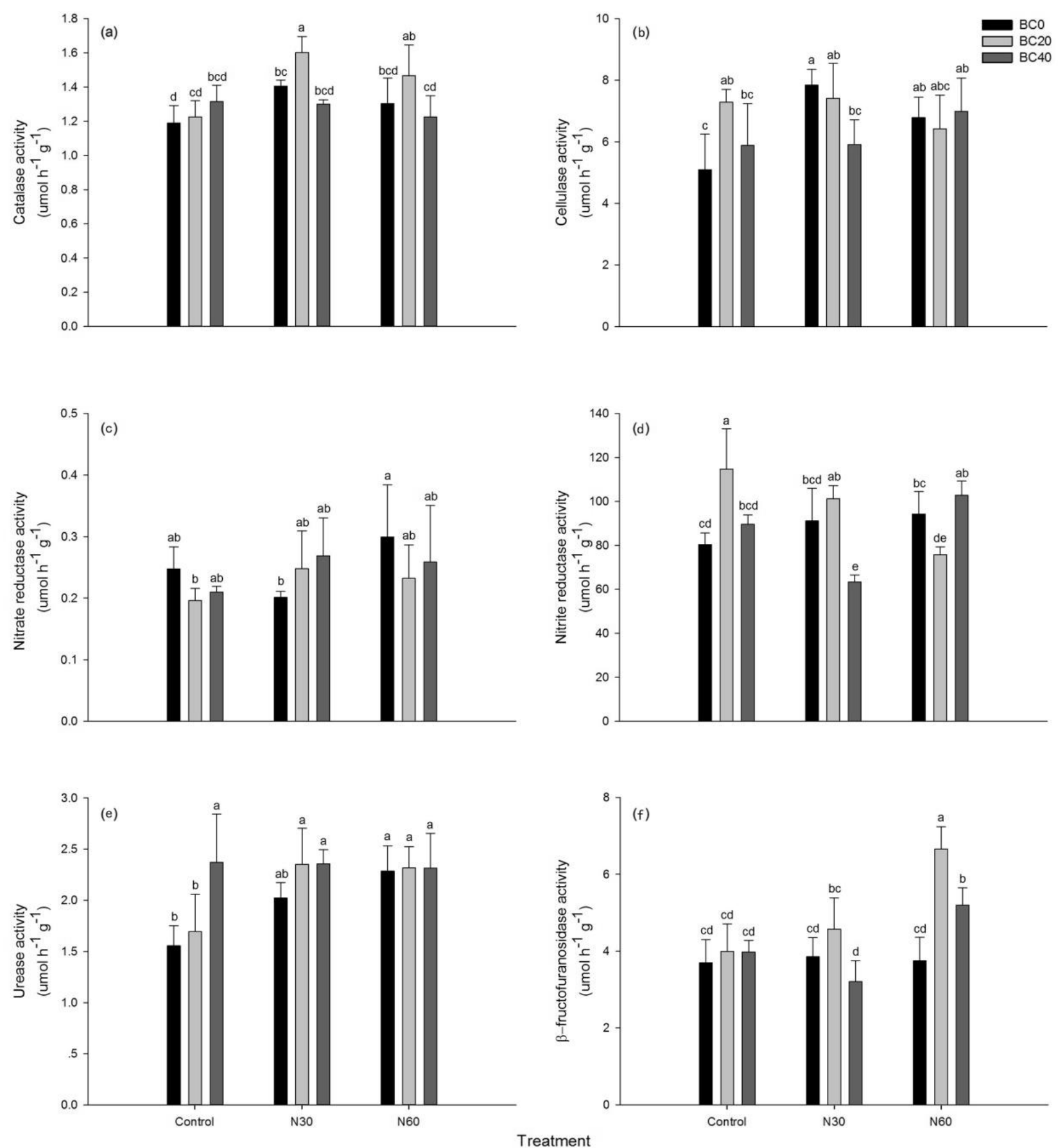

Fig. 2. Soil enzyme activity under nitrogen and biochar addition treatments in a Torreya grandis orchard: a) catalase, b) cellulase, c) nitrate reductase, d) nitrite reductase, e) urease, and(f) $\beta$-fructofuranosidase. N30: $30 \mathrm{~kg} \mathrm{~N} \mathrm{ha}^{-1} \cdot \mathrm{yr}^{-1} ; \mathrm{N} 60: 60 \mathrm{~kg} \mathrm{~N} \mathrm{ha}^{-1} \cdot \mathrm{yr}^{-1}$. BC20: 20 $\mathrm{t}$ biochar ha ${ }^{-1}$; BC40: $40 \mathrm{t}$ biochar ha ${ }^{-1}$. Data are the means of three replicates $( \pm \mathrm{SE})$. Different letters indicate significant differences at $P<0.05$. 
treatments than in the control (Fig. 2f). A two-way ANOVA showed that $\mathrm{N}$ deposition, biochar amendment, and their interaction all significantly affected $\beta$-fructofuranosidase activity (Table 2).

Our results showed that soil MBC significantly increased in N30 plots, but significantly decreased in N60 plots. This partially supports our first hypothesis, which was that $\mathrm{N}$ deposition increases soil MBC. It is generally known that $\mathrm{N}$ addition can alter microbial biomass and activity in several ways [4, 7]. Li et al. [27] found that $\mathrm{N}$ deposition $(30,60$, or $90 \mathrm{~kg}$ $\mathrm{N} \mathrm{ha}^{-1} \mathrm{yr}^{-1}$ ) significantly increased soil MBC in Moso bamboo (Phyllostachys edulis) plantations. However, a meta-analysis conducted by Treseder [6] showed that chronic $\mathrm{N}$ deposition significantly decreases MBC. Excessive $\mathrm{N}$ deposition can decrease the $\mathrm{C}: \mathrm{N}$ ratio of the soil organic matter, $\mathrm{pH}$, and soil organic $\mathrm{C}$ that are the energy sources for soil microorganisms [28], which leads to the decline in MBC.

Most enzyme activities were higher in the $\mathrm{N}$ treatments than they were in the control. The exception was nitrate reductase, which was lower in the N30 treatment than the control (Fig. 2), indicating that $\mathrm{N}$ addition significantly increased enzyme activity. These results also partially support our first hypothesis: that $\mathrm{N}$ deposition increases enzyme activities. Catalase is one of the major lignin-degrading enzymes found in the soil [29]. Waldrop et al. [30] found that catalase activity increased after one year of $\mathrm{N}$ addition in sugar maple (Acer saccharum Marshall) forests in northwestern Lower Michigan, USA. This is consistent with the results of the present study, suggesting that $\mathrm{N}$ deposition is beneficial for the promotion of lignin degradation and litter decomposition, and can accelerate nutrient cycling in T. grandis orchards. However, Deforest et al. [31] observed that catalase activity declines after nine years of $\mathrm{N}$ addition (30 kg N ha $\mathrm{kg}^{-1}$ ) in a mature northern

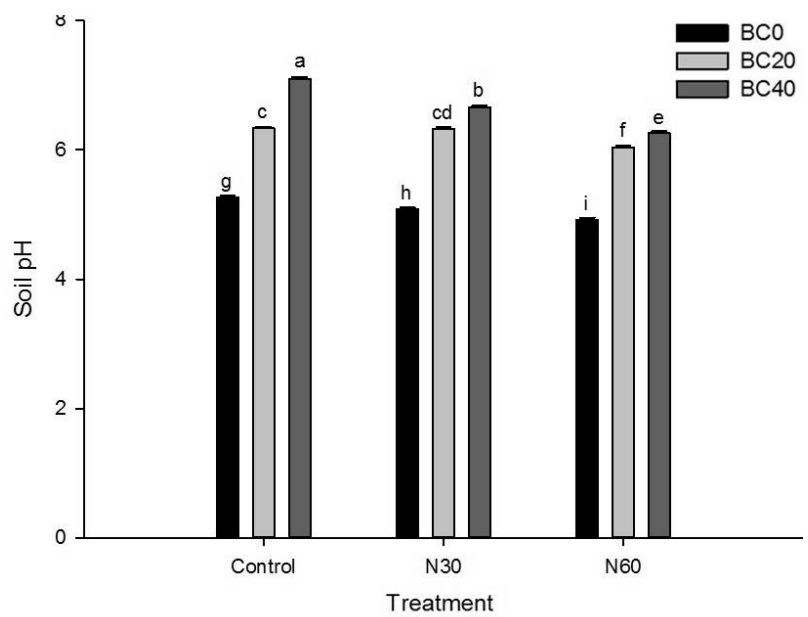

Fig. 3. Soil $\mathrm{pH}$ under nitrogen and biochar addition treatments in a Torreya grandis orchard. N30: $30 \mathrm{~kg} \mathrm{~N} \cdot \mathrm{ha}^{-1} \cdot \mathrm{yr}^{-1}$; N60: $60 \mathrm{~kg} \mathrm{~N} \cdot \mathrm{ha}^{-1} \cdot \mathrm{yr}^{-1}$. BC20: $20 \mathrm{t}$ biochar ha ${ }^{-1}$; BC40: $40 \mathrm{t}$ biochar $\mathrm{ha}^{-1}$. Data are the means of three replicates $( \pm \mathrm{SE})$. Different letters indicate significant differences at $P<0.05$. hardwood forest, and other studies have not found any significant effects [32]. Chronic $\mathrm{N}$ addition can reduce catechol and vanillin degradation, lignocellulose depolymerization, and soil microbial metabolism capacity; this may potentially explain why catalase activity was observed to decrease. These contradictory results imply that the effect of $\mathrm{N}$ deposition on catalase activity can vary with the timing of $\mathrm{N}$ deposition events.

Cellulase is produced by a great number of bacterial and fungal species [29]. A previous study found that the addition of $\mathrm{N}$ for seven years generally stimulated cellulase activity in eight forests and grassland sites with sandy, well drained, and poorly developed soils in Minnesota, USA [33], which is consistent with the results of the present study (Fig. 2b). In contrast, Liu et al. [34] observed that two levels of $\mathrm{N}$ addition (100 and $150 \mathrm{~kg} \mathrm{~N} \mathrm{ha}^{-1} \cdot \mathrm{y}^{-1}$ ) significantly decreased cellulase activity in natural Pinus tabuliformis Carrière forests on Taiyue Mountain, China. Cellulase activity is sensitive to alterations in soil $\mathrm{pH}$ [35]. Excessive $\mathrm{N}$ input can decrease soil pH (Fig. 3) and inhibit litter decomposition - especially the numbers and activity of microorganisms [36], leading to a decline in cellulase activity.

Nitrate reductase and nitrite reductase play important roles in soil denitrification, which are closely related to $\mathrm{NO}_{3}^{-}-\mathrm{N}$ concentrations [29]. In the present study, $\mathrm{N}$ deposition did not significantly affect the activities of these two enzymes (Fig. 2c, d; Table 2). Nonetheless, additional study is needed to fully understand these effects.

Urease is a type of $\mathrm{N}$-acquiring enzyme [37]. In the present study, $\mathrm{N}$ addition significantly increased urease activity (Fig. 2e; Table 2). Similar results were also obtained by Saiya-Cork et al. and Guan et al. [37, 38]. Saiya-Cork et al. [37] observed an increase in urease activity that suggested the potential for an increase in gross $\mathrm{N}$ mineralization rates during a study conducted in a sugar maple-dominated forest with simulated $\mathrm{N}\left(30 \mathrm{~kg} \mathrm{~N} \mathrm{ha}{ }^{-1} \cdot \mathrm{yr}^{-1}\right)$ deposition in northern Michigan, USA in the 1998-2000 growing seasons [37]. $\mathrm{N}$ deposition may improve the effectiveness of nitrogen, which strongly stimulates the transformation of urease activity. However, Ajwa et al. [39] observed that urease activity significantly decreased with $\mathrm{N}$ addition (100 kg N ha ${ }^{-1} \cdot \mathrm{yr}^{-1}$ ) to Irwin silty clay loam soil in a tall grass prairie ecosystem in Manhattan, USA, which is inconsistent with the results of the present study. This apparent contradiction is perhaps due to the high rate of $\mathrm{N}$ addition used in Ajwa et al. [39], who induced a negative effect on urease activity.

$\beta$-Fructofuranosidase serves not only as an indicator of the release of low molecular weight sugars, but also as an energy source for microorganisms [40]. Tu et al. [41] observed that $\beta$-fructofuranosidase activity significantly increased after six months of $\mathrm{N}$ addition in a Pleioblastus amarus (Keng) Keng f. plantation in a high-rainfall area of western China, which is inconsistent with the results of the present study (Fig. 2f). This is partly due to the large amount of fresh 
litter that contained soluble organic matter and cellulose present in the Pleioblastus amarus plantation, which increased $\beta$-fructofuranosidase activity.

\section{Effects of Biochar on Soil Microbial Biomass Carbon and Enzyme Activity}

MBC significantly decreased with an increasing rate of biochar amendment (Fig. 1), which supports our second hypothesis, which was that biochar amendment decreases soil MBC and enzyme activities. Similarly, Huang et al. [42] observed that a high rate of biochar amendment $\left(200 \mathrm{~g} \cdot \mathrm{kg}^{-1}\right)$ over the course of one year resulted in a decrease in MBC in high-fertility soil. A possible reason for this may be that biochar can adsorb low molecular weight organic matter, which can reduce soil MBC. The high $\mathrm{C}: \mathrm{N}$ ratio that can result from an excessive biochar amendment may cause soil microbial nitrogen immobilization, resulting in low microbial activity [43, 44]. Dempster et al. [45] found that soil MBC decreased with increasing rates of the addition of jarrah (Eucalyptus marginata Donn ex Sm.) wood biochar; one possible explanation for this observation is that the biochar input decreased the mineralization rate of the soil organic carbon. In addition, other studies have reported that soil organic carbon showed a significant positive correlation with soil MBC $[46,47]$. Li et al. [27] showed that high rates of biochar amendment (40 $\left.\mathrm{kg} \mathrm{ha}^{-1}\right)$ significantly decreased soil $\mathrm{MBC}$, but that moderate rates of biochar amendment $\left(20 \mathrm{~kg} \mathrm{ha}^{-1}\right)$ significantly increased soil MBC. The effects of biochar on soil microbes are controlled by multiple physicochemical and environmental factors.

Biochar amendment significantly increased cellulase, nitrite reductase, and urease activity, but had no significant effect on the other three enzymes examined in this study (Fig. 2). This contradicts our second hypothesis, that biochar amendment decreases enzyme activities. Catalase is a type of oxidoreductase, which indicates soil metabolic capacity [29]. In the present study, biochar amendment had no effect on catalase activity (Fig. 2a). Masto et al. [48] demonstrated that catalase activity significantly increased with increasing rates of biochar amendment $\left(0,1,3,5,10\right.$ and $\left.20 \mathrm{~g} \cdot \mathrm{kg}^{-1}\right)$ produced from water hyacinth in a red soil in India. In addition, catalase activity significantly increased with intermediate $\left(10 \mathrm{~g} \cdot \mathrm{kg}^{-1}\right)$ or low $\left(5 \mathrm{~g} \cdot \mathrm{kg}^{-1}\right)$ rates of biochar amendment, when compared with a high $\left(50 \mathrm{~g} \cdot \mathrm{kg}^{-1}\right)$ rate. An excessive rate of biochar amendment may inhibit enzyme catalysis binding sites via the absorption of enzyme molecules, which inhibits catalase activity [11].

Biochar is generally an alkaline material that can raise soil pH [35] (Fig. 3). In this study, it significantly increased cellulase activity (Fig. 2b). Similar results were observed by Bailey et al., Bamminger et al., and Paz-Ferreiro et al. [40, 49, 50]. However, Demisie et al. [51] found that three rates $\left(5 \mathrm{~g} \cdot \mathrm{kg}^{-1}, 10 \mathrm{~g} \cdot \mathrm{kg}^{-1}\right.$, and
$20 \mathrm{~g} \cdot \mathrm{kg}^{-1}$ ) of two kinds of biochar amendment (produced from oak wood and bamboo) had no effect on cellulase activity in a highly weathered, erosion-susceptible Chinese red soil.

In the present study, biochar amendment had no effect on nitrate reductase activity but significantly increased nitrite reductase activity (Fig. 2c, d; Table 2). In contrast, Zhang et al. [52] observed that the addition of biochar produced from apple tree branches increased nitrate reductase activity, but did not affect nitrite reductase, in the soil of a winter wheat system. These differences may be due to differences in biochar and ecosystem types.

Urease is sensitive to land use and agricultural management practices [40]. Previous studies [40, 51, 53, 54] have shown that biochar amendment has a positive effect on urease activity, which is consistent with our findings (Fig. 2e; Table 2). However, Gu et al. [55] found that biochar amendment produced from wheat straw significantly decreased urease activity in a grey desert soil, but did not decrease the activity of urease in an aeolian sandy soil. Wu et al. [56] observed that urease activity decreased with increasing rates $(0,9.9$, and $\left.24.4 \mathrm{~g} \cdot \mathrm{kg}^{-1}\right)$ of wheat straw biochar amendment in a chernozemic soil. The differences in these results imply that the effects of biochar on urease activity are complex.

$\beta$-Fructofuranosidase absorbs, utilizes, and provides energy for microorganisms via sucrose hydrolysis. The activity of this enzyme reflects its utilization of easily soluble substances, and the accumulation and transformation of microorganisms in the soil. In the present study, the high biochar amendment rate $\left(40 \mathrm{~g} \cdot \mathrm{kg}^{-1}\right)$ significantly increased the activity of $\beta$-fructofuranosidase, but the low biochar amendment rate did not (Fig. 2f). Similarly, Zou et al. [54] observed that a high biochar amendment rate $\left(50 \mathrm{~g} \cdot \mathrm{kg}^{-1}\right)$ had a positive effect on the activity of $\beta$-fructofuranosidase in the soil around cucumber roots.

\section{Interactive Effects of N Deposition and Biochar on Soil Microbial Biomass Carbon and Enzyme Activity}

Our results indicate that the low rate of biochar (20 tonnes $\cdot \mathrm{ha}^{-1}$ ) amendment of the N30 plots amplified the positive effect of $\mathrm{N}$ deposition on the $\mathrm{MBC}$ (Fig. 1). In contrast, the high rate of biochar (40 tonnes $\cdot \mathrm{ha}^{-1}$ ) amendment of the N30 plots inhibited this positive effect (Fig. 1). In the N60 plots, biochar amendment significantly alleviated the negative effect of $\mathrm{N}$ deposition on the soil MBC, and even transformed it to a positive effect (Fig. 1). This pattern partly supports the third hypothesis - that biochar amendment offsets the negative effect of $\mathrm{N}$ deposition - and indicates that biochar amendment can change the effects of $\mathrm{N}$ deposition on enzyme activity. The results of the present study also suggest that soil $\mathrm{pH}$ affected MBC. Low biochar amendment neutralized the acidity of 
the soil in the N30 plots, and therefore increased the soil MBC (Fig. 1). However, high $\mathrm{pH}$ values induced by high rates of biochar amendment (40 tonnes ${ }^{-1} \mathrm{a}^{-1}$ ) resulted in a negative effect on soil MBC (Figs 1, 3). In the N60 plots, excessive $\mathrm{N}$ deposition largely decreased soil $\mathrm{pH}$, while biochar amendment significantly increased the $\mathrm{pH}$ of acidic soils (Fig. 3) and therefore significantly increased soil MBC (Fig. 1). Biochar amendment was also observed to reverse the reduction in the soil MBC caused by the high rate of $\mathrm{N}$ addition (Fig. 1). One reason for this may be that the physicochemical properties of biochar, for example its alkaline $\mathrm{pH}$, could not only improve soil $\mathrm{pH}$, but also the water-holding capacity and CEC of the soil. Biochar can create a favorable habitat for microbial colonization due to its large surface area and porous structure [57]. Our findings suggest that the direction and magnitude of variation of soil MBC depends on the rates of both biochar and $\mathrm{N}$ addition

Nitrogen addition significantly increased catalase and cellulase activities. A low rate of biochar amendment significantly amplified the positive effects of the low rate of $\mathrm{N}$ addition on catalase, but significantly offset the positive effects on cellulase. Biochar amendment of the N60 plots significantly increased $\beta$-fructofuranosidase activity, although $\mathrm{N}$ addition did not have a significant effect. Our findings indicate that the effects of biochar amendment of soil receiving atmospheric $\mathrm{N}$ deposition were regulated by the rates of both biochar amendment and $\mathrm{N}$ deposition, and varied with enzyme type.

\section{Conclusions}

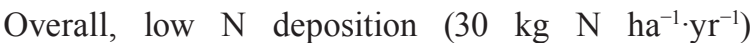
increased soil $\mathrm{MBC}$, whereas high $\mathrm{N}$ deposition (60 $\mathrm{kg} \mathrm{N} \mathrm{ha} \mathrm{Nar}^{-1}$ ) decreased it. The addition of $\mathrm{N}$ increased enzyme activity with the exception of nitrate reductase activity, which decreased slightly in the N30 plots. Biochar amendment significantly decreased $\mathrm{MBC}$, but increased enzyme activity with the exception of nitrate reductase activity that was observed to decline after biochar amendment. When combined with the addition of $\mathrm{N}$, biochar amendment could significantly alter the effects of $\mathrm{N}$ deposition on $\mathrm{MBC}$ and enzyme activity. Our findings indicated that $\mathrm{N}$ deposition and biochar amendment, both individually and combined, significantly affected soil $\mathrm{MBC}$ and enzyme activity in a $T$. grandis orchard. The direction and magnitude of these effects depended on the rates of both biochar amendment and $\mathrm{N}$ addition.

\section{Acknowledgements}

This study was funded by the National Natural Science Foundation of China (grant Nos. 31570616, 31470529).

\section{Conflict of Interest}

The authors have not declared any conflict of interest.

\section{References}

1. GALLOWAY J.N., TOWNSEND A.R., ERISMAN J.W., BEKUNDA M., CAI Z., FRENEY J.R., MARTINELLI L.A., SEITZINGER S.P., SUTTON M.A. Transformation of the nitrogen cycle: recent trends, questions, and potential solutions. Science 320, 889, 2008.

2. CHANG Y., LIU X., LI K., LV J., SONG W. Research Progress in Atmospheric Nitrogen Deposition. Arid Zone Research 29, 972, 2012.

3. SETIA R., VERMA S.L., MARSCHNER, P. Measuring microbial biomass carbon by direct extraction Comparison with chloroform fumigation-extraction. Eur. J. Soil Biol. 53, 103, 2012.

4. COMPTON J.E., WATRUD L.S., PORTEOUS L.A., DEGROOD S. Response of soil microbial biomass and community composition to chronic nitrogen additions at Harvard forest. For. Ecol. Manage. 196, 143, 2004.

5. LI L., ZENG D., YU Z., FAN Z., MAO R. Soil microbial properties under $\mathrm{N}$ and $\mathrm{P}$ additions in a semi-arid, sandy grassland. Biol. Fertil. Soils 46, 653, 2010.

6. TRESEDER K.K. Nitrogen additions and microbial biomass: a meta-analysis of ecosystem studies. Ecol. Lett. 11, 1111, 2008.

7. JOHNSON D., LEAKE J.R., LEE J.A., CAMPBELL C.D. Changes in soil microbial biomass and microbial activities in response to 7 years simulated pollutant nitrogen deposition on a heathland and two grasslands. Environ. Pollut. 103, 239, 1998.

8. BOXMAN A.W., BLANCK K., BRANDRUD T.E., EMMETT B.A., GUNDERSEN P., HOGERVORST R.F., KJONAAS O.J., PERSSON H., TIMMERMANN $\mathrm{V}$. Vegetation and soil biota response to experimentallychanged nitrogen inputs in coniferous forest ecosystems of the NITREX project. For Ecol. Manage. 101, 65, 1998.

9. HU B., WANG Y., WANG Y., WANG B., ZHANG H., PING G., LIU C. Effects of simulated nitrogen deposition on soil acidification and soil buffering capacity. Res. Environ. Sci. 28, 418, 2015.

10. WANG Z. The impact of simulated nitrogen deposition on soil microbia in sub-tropical plantation. Central South University of Forestry and Technology, 2012.

11. LI L., LIU Y., LU Y., LIANG Z., ZHANG P., SUN H. Review on environmental effects and applications of biochar. Environmental Chemistry 30, 1411, 2011.

12. KUZYAKOV Y., BOGOMOLOVA I., GLASER B. Biochar stability in soil: Decomposition during eight years and transformation as assessed by compound-specific ${ }^{14} \mathrm{C}$ analysis. Soil Biol. Biochem. 70, 229, 2014.

13. PAN G., BIAN R., CHENG K. From biowaste treatment to novel bio-material manufacturing: Biomaterial science and technology based on biomass pyrolysis. Science \& Technology Review 35, 2017.

14. ZHANG X., LIU X.R., LIN G.L., ZHANG Q.W., ZHANG Q.Z., WANG Q. Effects of biochar and straw return on mineral nitrogen and $\mathrm{pH}$ of the surface soil in farmland of the North China Plain. Chinese Journal of Agrometeorology 37, 131, 2016. 
15. ZHAO R., COLES N., WU J. Carbon mineralization following additions of fresh and aged biochar to an infertile soil. Catena 125, 183, 2015.

16. JIEN S.H., WANG C.S. Effects of biochar on soil properties and erosion potential in a highly weathered soil. Catena 110, 225, 2013.

17. LIU S., ZHANG Y., ZONG Y., HU Z., WU S., ZHOU J., JIN Y., ZOU J. Response of soil carbon dioxide fluxes, soil organic carbon and microbial biomass carbon to biochar amendment: a meta-analysis. GCB Bioenergy 8, 392, 2016.

18. FENG A., ZHANG M., LI C., YANG Y., CHEN B. Effects of straw and straw biochar on wheat nutrient uptake and enzyme activity in brown soil. Acta Ecol. Sin. 35, 5269, 2015.

19. ZHANG C. Soil fertility in orchards and plant nurtrition and fertilization of Torreya grandis Merrillii. Zhejiang A\&F University, 2011.

20. SONG X., ZHOU G., GU H., QI L. Management practices amplify the effects of $\mathrm{N}$ deposition on leaf litter decomposition of the Moso bamboo forest. Plant Soil 395, 391, 2015.

21. SONG X., LI Q., GU H. Effect of nitrogen deposition and management practices on fine root decomposition in Moso bamboo plantations. Plant Soil 410, 207, 2016.

22. CUI J., ZHOU J., PENG Y., HE Y., YANG H., MAO J., ZHANG M., WANG Y., WANG S. Atmospheric wet deposition of nitrogen and sulfur in the agroecosystem in developing and developed areas of southeastern China. Atmos Environ. 89, 102, 2014.

23. JIA Y., YU G., HE N., ZHAN X., FANG H., SHENG W., ZUO Y., ZHANG D., WANG Q. Spatial and decadal variations in inorganic nitrogen wet deposition in China induced by human activity. Sci. Rep. 4, 3763, 2014.

24. OLMO M., LOZANO A.M., BARRÓN V., VILLAR R. Spatial heterogeneity of soil biochar content affects soil quality and wheat growth and yield. Sci. Total Environ. 562, 690, 2016.

25. LI Q., SONG X., GU H., GAO F. Nitrogen deposition and management practices increase soil microbial biomass carbon but decrease diversity in Moso bamboo plantations. Sci. Rep. 6, 28235, 2016.

26. GUAN S. Soil enzyme and its study methods. Beijing: China Agriculture Press 1986.

27. LI Q., LEI Z., SONG X., ZHANG Z., YING Y., PENG C. Biochar amendment decreases soil microbial biomass and increases bacterial diversity in Moso bamboo (Phyllostachys edulis) plantations under simulated nitrogen deposition. Environ. Res. Lett. 13, 2018.

28. ZHOU X., ZHANG Y., DOWNING A. Non-linear response of microbial activity across a gradient of nitrogen addition to a soil from the Gurbantunggut Desert, northwestern China. Soil Biol. Biochem. 47, 67, 2012.

29. WANG L., WANG F., GUO C., HAN F., WEI L., LI F. Review: Progress of Soil Enzymology. Soils 48, 12, 2016.

30. WALDROP M.P., ZAK D.R., SINSABAUGH R.L. Microbial community response to nitrogen deposition in northern forest ecosystems. Soil Biol. Biochem. 36, 1443, 2004.

31. DEFOREST J.L., ZAK D.R., PREGITZER K.S., BURTON A.J. Atmospheric nitratedeposition and the microbial degradation of cellobiose and vanillin in a northern hardwood forest. Soil Biol. Biochem. 36, 965, 2004.

32. HOBBIE S.E., VITOUSEK P.M. Nutrient limitation of decomposition in Hawaiian forests. Ecology 81, 1867, 2000.
33. KEELER B.L., HOBBIE S.E., KELLOGG L.E. Effects of long-term nitrogen addition on microbial enzyme activity in eight forested and grassland sites: Implications for litter and soil organic matter decomposition. Ecosystems 12, 1, 2009.

34. LIU X., WANG J., ZHAO X. Effects of simulated nitrogen deposition on the soil enzyme activities in a Pinus tabulaeformis forest at the Taiyue Mountain. Acta Ecol. Sin. 35, 4613, 2015.

35. GASCÓ G., PAZ-FERREIRO J., CELY P., PLAZA C., MÉNDEZ A. Influence of pig manure and its biochar on soil $\mathrm{CO}_{2}$ emissions and soil enzymes. Ecol. Eng. 95, 19, 2016.

36. SONG X., JIANG H., ZHANG Z., ZHOU G., ZHANG S., PENG C. Interactive effects of elevated UV-B radiation and $\mathrm{N}$ deposition on decomposition of Moso bamboo litter. Soil Biol. Biochem. 69, 11, 2014.

37. SAIYA-CORK K.R., SINSABAUGH R.L., ZAK D.R. The effects of long term nitrogen deposition on extracellular enzyme activity in an Acer saccharum forest soil. Soil Biol. Biochem. 34, 1309, 2002.

38. GUAN G., TU S., YANG J., ZHANG J., LI Y. A field study on effects of nitrogen fertilization modes on nutrient uptake, crop yield and soil biological properties in ricewheat rotation system. Agric. Sci. China 10, 1254, 2011.

39. AJWA H.A., DELL C.J., RICE C.W. Changes in enzyme activities and microbial biomass of tallgrass prairie soil as related to burning and nitrogen fertilization. Soil Biol. Biochem. 31, 769, 1999.

40. PAZ-FERREIRO J., FU S., MÉNDEZ A., GASCÓ G. Interactive effects of biochar and the earthworm Pontoscolex corethrurus on plant productivity and soil enzyme activities. J. Soils Sediments 14, 483, 2014.

41. TU L., HU T., ZHANG J., LI R., DAI H., LUO S., XIANG Y., HUANG L. Soil enzyme activities in a Pleioblastus amurus plantation in rainy area of west China under simulated nitrogen deposition. Chin. J. Appl. Ecol. 20, 2943, 2009.

42. HUANG C., LIU L., ZHANG M. Effects of biochar on properties of red soil and ryegrass growth. J. Zhejiang Univ. 37, 439, 2011.

43. AMELOOT N., GRABER E.R., FGA V., DE N.S. Interactions between biochar stability and soil organisms: Review and research needs. Eur. J. Soil Sci. 64, 379, 2013.

44. SDC C., MCNAMARA N.P., REAY D.S., WHITAKER J. The effect of biochar addition on $\mathrm{N}_{2} \mathrm{O}$ and $\mathrm{CO}_{2}$ emissions from a sandy loam soil - The role of soil aeration. Soil Biol. Biochem. 51, 125, 2012.

45. DEMPSTER D.N., GLESSON D.B., SOLAIMAN Z.M., JONES D.L., MURPHY D.V. Decreased soil microbial biomass and nitrogen mineralisation with Eucalyptus biochar addition to a coarse textured soil. Plant Soil 354, 311, 2012.

46. CHEN H., SU D., LV X., XU H., LIN R., JIANG B. Dynamic characteristics of soil organic carbon and microbial biomass carbon ofevergreen broad-leaved Forest in Wuyi Mountain. Journal of Agriculture 1, 38, 2011.

47. ZHOU Y., HAO K., LI X., FAN C., CHEN S., LIU Y., WANG X. Effects of forest gap on seasonal dynamics of soil organic carbon and microbial biomass carbon in Picea asperata forest in Miyaluo of Western Sichuan, Southwest China. Chin. J. Appl. Ecol. 25, 2469, 2014.

48. MASTO R.E., KUMAR S., ROUT T.K., SARKAR P., GEORGE J., RAM L.C. Biochar from water hyacinth (Eichornia crassipes) and its impact on soil biological activity. Catena 111, 64, 2013. 
49. BAILEY V.L., FANSLER S.J., SMITH J.L., JR H.B. Reconciling apparent variability in effects of biochar amendment on soil enzyme activities by assay optimization. Soil Biol. Biochem. 43, 296, 2011.

50. BAMMINGER C., MARSCHNER B., JÜSCHKE E. An incubation study on the stability and biological effects of pyrogenic and hydrothermal biochar in two soils. Eur. J. Soil Sci. 65, 72, 2014.

51. DEMISIE W., LIU Z., ZHANG M. Effect of biochar on carbon fractions and enzyme activity of red soil. Catena 121, 214, 2014.

52. ZHANG W., HE X., GENG Z., YIN X., WANG Q., SUN Y. Effects of different biochar-based nitrogen fertilizers on nitrogen accumulation and biological activities in soilwinter wheat system. J. Agro-Environ. Sci. 33, 1394, 2014.

53. OLESZCZUK P., JOŚKO I., FUTA B., PASIECZNAPATKOWSKA S., PAŁYS E., KRASKA P. Effect of pesticides on microorganisms, enzymatic activity and plant in biochar-amended soil. Geoderma 214, 10, 2014.
54. ZOU C., ZHANG Y., ZHANG Y., GUO X., LI M., LI T. Regulation of biochar on matrix enzyme activities and microorganisms around cucumber roots under continuous cropping. Chin. J. Appl. Ecol. 26, 1772, 2015.

55. GU M., XU W., TANG G., GE C., MA H. Effects of biochar on soil microbial diversity and function related with $\mathrm{N}$ transformation in grey desert soil and aeolian sandy soil in Xinjiang. Xinjiang Agricultural Sciences 51, 926, 2014.

56. WU F., JIA Z., WANG S., STARTSEV A. Contrasting effects of wheat straw and its biochar on greenhouse gas emissions and enzyme activities in a Chernozemic soil. Biol. Fertil. Soils 49, 555, 2013.

57. JAAFAR N.M., CLODE P.L., ABBOTT L.K. Soil microbial responses to biochars varying in particle size, surface and pore properties. Pedosphere 25, 770, 2015. 